\title{
Articles
}

\section{THE CONCEPT OF INTERNAL DISPLACEMENT AND THE CASE FOR INTERNALLY DISPLACED PERSONS AS A CATEGORY OF CONCERN}

\section{Erin Mooney*}

It has now been some fifteen years since the issue of internal displacement indelibly was placed on the international agenda and recognized as a legitimate matter of international concern. Since that time, awareness of the global crisis of internal displacement and of the plight of affected populations has grown. A normative framework for addressing the problem has been developed and its use is being widely promoted at the national, regional and international levels. International humanitarian, human rights and development agencies have become increasingly engaged with the internally displaced, both at the policy level and in the field, and a UN office has been established to coordinate their efforts and ensure an effective international response. In a sign of the wide recognition it has attained, the issue of internal displacement now features regularly in international discourse, and not only in human rights and humanitarian circles but also in the debates of the UN Security Council.

Despite being firmly embedded in the international lexicon, however, there is question as to whether "internal displacement" has become a term of art. In fact, there exist different ideas as to what is meant by "internal displacement" and "internally displaced persons". For some, the term "internally displaced persons" refers only to people uprooted by conflict, violence and persecution, that is, people who would be considered refugees if they crossed a border. Global statistics on internally displaced persons generally reinforce this view by counting only those displaced by conflict. Others, however, consider internal displacement to be a much broader concept and to encompass the millions more persons uprooted by natural disasters and development projects. Still others question whether it is useful to single out internally displaced persons, who commonly are referred to as "IDPs", as a category at all. There also is no consensus on "when internal displacement ends", that is, when an IDP should no longer be considered as such. Confounding matters further is that in common parlance the internally displaced often are referred to as "refugees", which tends to be a catch-all phrase to describe all uprooted peoples without regard to whether they have left the country, as the legal definition of "refugee" requires. In short, there is a need for clarity on a number of conceptual issues.

Deputy Director, Brookings Institution-University of Bern Project on Internal Displacement and Senior Adviser to the Representative of the United Nations Secretary-General on the Human Rights of Internally Displaced Persons. Email: emooney@brookings.edu. The author is grateful to Megan Bradley for research assistance as well as to Roberta Cohen for providing comments helpful in the preparation of this article. 
This article will examine the concept of internal displacement by considering three key questions that commonly arise. First, it will discuss definitional issues and the different points of view as to who is an IDP. Second, it will explore the debate as to whether IDPs should even be a special category of concern. Third, there is the question of when internal displacement ends or, in other words, when would it be appropriate to cease identifying IDPs as such. Exploring these questions is not simply an academic or theoretical exercise. Indeed, how they are answered can have a tremendous impact on the lives of millions of people uprooted within their own countries and in particular on the respect for their human rights.

\section{WHO IS AN IDP?}

When the issue of internal displacement emerged onto the international agenda in the early 1990s, no definition of "internally displaced persons" existed. Yet, having a definition was essential for identifying the populations of concern and their particular needs, compiling data, and framing laws and policies designed to assist them. Developing a definition for this group of people was therefore a key task for the Representative of the United Nations Secretary-General on Internally Displaced Persons at the outset of his mandate. ${ }^{1}$ Given the range of views on the matter, this proved to be a challenging task. ${ }^{2}$

Two core elements of the concept of internal displacement were clear. One, was the involuntary nature of the movement. Two, was the fact that such movement takes place within national borders - a criterion which distinguished the internally displaced from refugees who, according to international law, by definition are outside of their country. ${ }^{3}$ Beyond this, however, the parameters of the concept needed to be defined.

A starting point was the working definition that had been put forth in 1992 by the United Nations Secretary-General, which defined internally displaced persons as:

"Persons or groups who have been forced to flee their homes suddenly or unexpectedly in large numbers, as a result of armed conflict, internal strife, systematic violations of human rights or natural or man-made disaster, and who are within the territory of their own country". ${ }^{4}$

This definition reflected a range of circumstances in which the core characteristics of internal displacement - involuntary movement within borders - could arise. In part, the causes listed were drawn from the broader refugee definitions used in Africa and Latin America that extend beyond the persecution criterion in the 1951 Refugee Convention to also encompass persons fleeing from armed conflict, internal strife and systematic violations of human rights. ${ }^{5}$ However, the definition went even further by including persons uprooted by natural disasters and human- made disasters. There had been many cases where floods, earthquakes and famine as well as human-made disasters, such as nuclear or chemical accidents, had uprooted populations, and it could not be discounted that these were also major causes of population displacement. A definition that was broad enough to take these other causes into account therefore was required. 
At the same time, the 1992 definition was determined to be too narrow in other respects, in particular its temporal and numerical criteria. To limit the IDP concept only to those who had fled their homes "suddenly or unexpectedly" overlooked that in a number of situations, such as in Burma, Ethiopia and Iraq, the displacement of populations was not a spontaneous event but an organized state policy implemented over years or even decades. Similarly, the criterion of being "forced to flee" would exclude all those situations where populations did not flee but were obliged to leave their homes, as for instance with the forced evictions of minorities during the war in Bosnia or, more recently in the summer of 2005, in Zimbabwe with the home demolitions and forced removal of more than half a million people. Also problematic was the notion of people fleeing "in large numbers" as in reality many displaced fled in small groups or even on an individual basis. The definition eventually arrived at by the Representative of the SecretaryGeneral therefore eliminated any requirements regarding time or the minimum number of persons affected.

Several important nuances were introduced. In recognition that people could become internally displaced not only as a consequence of suffering the causes of displacement but also in anticipation of such effects, reference was made to people having fled "as a result of or in order to avoid the effects of" the causes listed in the definition. As persons did not necessarily have a home, reference was also made to "habitual places of residence". Finally, the criterion of being "within the territory of their own country" was altered to "who have not crossed an internationally recognized State border", to reflect the possibility of sudden border changes, for instance as had occurred with the break-up of the former Yugoslavia and the dissolution of the Soviet Union.

The definition that eventually emerged from the Representative's deliberations is contained in the introduction to the Guiding Principles on Internal Displacement. The Principles, which were presented to the UN in 1998 have since gained wide recognition as an important tool and a standard for addressing internal displacement and are being used around the world by governments, the United Nations, regional bodies, non-governmental organizations and other actors. They define internally displaced persons as:

"Persons or groups of persons who have been forced or obliged to flee or to leave their homes or places of habitual residence, in particular as a result of or in order to avoid the effects of armed conflict, situations of generalized violence, violations of human rights or natural or human-made disasters, and who have not crossed an internationally recognized State border". ${ }^{6}$

The various causes of internal displacement identified in the 1992 working definition all were retained. However, in recognition that internal displacement was not necessarily limited to these causes alone, the definition in the Principles prefaces the list of causes with the qualifier "in particular" so as not to exclude the possibility of other situations that meet the key core criteria of involuntary movement within one's country.

In the deliberations leading to this definition, there were those who would have preferred to limit the IDP definition to persons subject to persecution or 
conflict, that is, to persons who would be considered refugees if they crossed a border. Early on, however, many non-governmental organizations had pointed out that to limit the IDP definition in this way ran the risk of formulating a definition that did 'not accurately depict the variety of the root causes of displacement,' among which were development projects and natural disasters. ${ }^{7}$ In the end, the 'overriding opinion' was that persons uprooted by natural and human-made disasters or development projects were also displaced and in need of attention, not least because as experience had shown they too could be discriminated against and subject to human rights violations in the course of their displacement. ${ }^{8}$

Even so, the decision to include these groups in the definition of IDPs has not yet been fully taken on board. Global statistics on internal displacement generally count only IDPs uprooted by conflict and human rights violations. ${ }^{9}$ Moreover, a recent study has recommended that the IDP concept should be defined even more narrowly, to be limited to persons displaced by violence. ${ }^{10}$

However, persons uprooted by natural disasters are also, factually speaking, internally displaced. They often also are in need of humanitarian assistance and, in some cases, protection as well. The massive displacement crisis resulting from the December 2004 tsunami in Southeast Asia has helped to focus attention on the needs of these IDPs. It also has confirmed the relevance of bringing together under one definition the different scenarios in which internal displacement can arise. As the Representative of the Secretary-General on the Human Rights of Internally Displaced Persons, Walter Kälin, noted after visiting the tsunami-affected region 'persons forced to flee their homes share many common types of vulnerability regardless of the underlying reasons for their displacement.' ${ }^{11}$ Indeed, long before the devastating 2004 tsunami, governments in other regions have been among those highlighting disasters as a cause of internal displacement and an issue requiring greater attention. ${ }^{12}$ Moreover, it is noteworthy that the guidance issued to the UN's Humanitarian and Resident Coordinators, who are responsible for ensuring an effective UN response to internal displacement in each affected country, recognizes that internal displacement results from a range of causes, and explicitly refers to "natural and human-made disasters". ${ }^{13}$

The lack of explicit mention of development in the IDP definition has sometimes led to confusion, including erroneous assertions that those displaced as a result of development projects are excluded from the Guiding Principles. ${ }^{14}$ However, that the Guiding Principles were meant to also apply in situations of development is apparent from the content of the Principles themselves, which directly address displacement by development projects in Principle 6 and also draw upon resettlement standards from the development field. ${ }^{15}$ In many parts of the world, in particular Asia, the idea that persons forced to relocate by development projects are not displaced would ring hollow. At a regional conference on internal displacement in Asia co-sponsored by UNHCR, the Asia Forum for Human Rights and Development, the Norwegian Refugee Council, the U.S. Committee for Refugees and the Brookings Institution in 2000, it became clear that any discussion of internal displacement in the region would not be complete without taking into account displacement due to development projects. ${ }^{16}$ Underscoring this point is a 
recent volume on the application of the Guiding Principles in South Asia, which covers displacement by conflict and disaster as well as development projects. ${ }^{17} \mathrm{By}$ no means is this view limited to the region. In West Africa, governments of the Economic Community of West African States (ECOWAS) recommended that in developing a glossary of migration terms for the region, development as a cause of displacement should be explicitly added to the IDP definition contained in the Guiding Principles. ${ }^{18}$ The Global IDP Project, while citing the figure of 25 million IDPs displaced by conflict nonetheless acknowledges that the number of people uprooted by development projects is thought to be much higher, and notes that both groups are covered by the Principles. Furthermore, it points out that in the case of development-induced IDPs, ' $[\mathrm{t}$ ] heir plight remains largely unnoticed and they often receive even less support from their government and/or international aid agencies than people displaced by conflict or natural disasters. ${ }^{19}$

Expanding the IDP definition further to encompass persons who migrate because of extreme poverty or other economic problems had been proposed during the formulation of the definition and to this day is a suggestion that sometimes is put forth. The IDP definition, however, does not extend to these groups. This is because in most cases the element of coercion is not so clear. ${ }^{20}$ The decision to exclude economic migrants and migrant workers from the IDP definition does not mean there is not a need for special attention to their situation and human rights, but simply that different issues are involved. As Robert Goldman, one of the members of the legal team that drafted the Guiding Principles has explained, the reason for framing an IDP definition, was to address the plight of a particular group of persons who had distinct protection and assistance needs resulting from forced displacement; to enlarge the definition would risk losing this focus. ${ }^{21}$ Indeed, there are cases where a government has categorized IDPs as "migrants", presumably to deflect attention from the involuntary nature of their movement and thereby to avoid its responsibilities towards them. For these reasons, the distinction between IDPs and economic migrants is important to maintain.

In summary, although internally displaced persons often are described as "internal refugees", in fact, internal displacement is much broader than the refugee concept. It is not limited to conflict and persecution but covers other causes of forced displacement including natural disasters and also can encompass people forced to relocate by development projects. Despite these very different causes, the various groups of uprooted people were included together in one definition as they have in common the two core criteria of involuntary movement and being within one's borders. The IDP definition therefore tries to strike a balance between too narrow a framework that risks excluding people who share similar characteristics and one so broad that it loses the focus on the distinct protection and assistance needs arising from forced displacement.

It is important to bear in mind that the definition of "internally displaced person" is a descriptive, rather than legal, definition. It simply describes the factual situation of a person being displaced within one's country of habitual residence. The term does not connote or confer a special legal status in the same way that recognition as a "refugee" does. This is not necessary for IDPs, Walter Kälin 
explains, because whereas refugees having lost the protection of their own country and being outside of their own state therefore require a special legal status, 'the rights and guarantees to which IDPs are entitled stem from the fact that they are human beings and citizens or habitual residents of a particular state. ${ }^{.22}$

Another important distinction with the "refugee" concept is that not all situations of internal displacement will necessarily be of concern to the international community. ${ }^{23}$ If the needs of internally displaced populations are met effectively by their own government, the international community need not become involved, unless of course the government requests assistance. If, on the other hand, internally displaced persons are denied the protection and assistance of their government, they are of legitimate concern to the international community. Of course, not all IDPs will be of concern to each organization that has a mandate or readiness to engage in situations of internal displacement. Because the IDP definition is a descriptive rather than legal definition, it allows for organizations to adapt the IDP concept to their particular mandates and institutional perspectives. For instance, the International Committee of the Red Cross (ICRC), given its mandate in armed conflicts, inevitably will focus on those IDPs uprooted by armed conflict. ${ }^{24}$ Staff may even define IDPs accordingly..$^{25}$ The organization nevertheless acknowledges the broader IDP definition, which the ICRC finds to be 'fully suited for the purposes of the Guiding Principles. ${ }^{26}$ After all, the ICRC recognizes that internal displacement results from a number of causes, of which armed conflict is but one and simply the cause with which it is centrally concerned. ${ }^{27}$ Similarly, United Nations High Commissioner for Refugees (UNHCR) answers the question of "Who is an IDP?" by employing a definition that reflects the same array of causes indicated in the Guiding Principles, all the while specifying that UNHCR helps "some" of these people, in particular IDPs uprooted by conflict or persecution. ${ }^{28}$ The fact that an organization chooses to conceptualize IDPs based on the organization's particular mandate and activities does not detract from the definition in the Guiding Principles. To the contrary, it underscores that there is all the more reason to have a general definition covering all the different aspects of internal displacement.

\section{IDPS AS A SPECIAL CATEGORY OF CONCERN?}

Definitional issues aside, questions sometimes arise as to whether the internally displaced should even be the subject of focused attention and considered as a specific category of concern. Certainly, this was a point of considerable debate within humanitarian as well as academic circles when the IDP issue first emerged onto the international agenda. It is a question that continues to surface to this day. One view has been that rather than identifying IDPs as a specific category of concern they should simply be treated as victims of war. ${ }^{29} \mathrm{O}$ course, this argument ignores that displacement arises from other causes than conflict. A more fundamental objection against considering the internally displaced as a specific category has been the concern that singling out this group will privilege the displaced and lead to discrimination against others. ${ }^{30} \mathrm{~A}$ recent study has once again brought this ques- 
tion to the fore, finding there to be 'a strong vein of objection, not only to the treatment of IDPs as a separate category but even to their separate identification amongst all actual and potential vulnerable groups. ${ }^{31}$

However, there are many arguments to be made on the other side that seem to be more persuasive and point to the importance of identifying the internally displaced as a distinct group whose needs warrant specific attention. To begin with, in many cases internally displaced persons are the victims of a deliberate policy targeting them for displacement and forced relocation. Minority groups have been particularly vulnerable to this practice, which often occurs along ethnic or religious lines and amounts to what has become known as "ethnic cleansing", which prima facie violates the principle of non-discrimination. In war situations, international humanitarian law prescribes that unless the security of the civilians involved or imperative military reasons so demand, any decision for the displacement of populations is prohibited. In addition, under international criminal law, the forced removal of populations, including outside of the context of armed conflict, is now recognized as a crime against humanity. Based on these standards as well as various implicit prohibitions in international human rights law, a right not to be arbitrarily displaced has been articulated. ${ }^{32}$ The very fact of being internally displaced therefore can signal a deliberate abuse of rights. Indeed, the same study reporting that there continues to exist a constituency for the view that calls into question the "categorization of IDPs" points out that internal displacement 'is directly associated with the violation of certain rights. ${ }^{33}$

Once it occurs, internal displacement brings about a set of circumstances that renders those affected highly vulnerable. Most obviously, it forces people from their homes, depriving them of shelter and the basic protection it can provide. Cut off from their land, traditional livelihood and means of generating income, and compelled to leave all but a few possessions behind, IDPs suddenly find themselves stripped of their means of survival. At the same time, it breaks up families and community support networks. As one recent study underscored, displacement leads to 'massive loss not only of commodities such as the home, income, land or other forms of property, but also of less tangible symbolic goods, such as cultural heritage, friendship and a sense of belonging to a particular place.' Its 'pernicious effects on individuals, families and communities' are wide-ranging and include 'impoverishment, social isolation, exclusion from health, welfare and education provision, the breakdown of social relationships and support structures, and the undermining of authority structures and social roles. ${ }^{34}$ Children are particularly affected as displacement not only disrupts their education and normal development but also frequently results in their being separated from their families in the chaos of flight, left to fend for themselves and at heightened risk of abuse. Compounding their plight, the displaced often are stigmatized and may also be viewed with suspicion and hostility in the areas to which they flee. They are especially vulnerable to acts of violence and human rights violations, including round-ups, forced conscription and sexual assault. It is noteworthy that the ICRC, which was among those initially espousing the view that IDPs in war situations should be treated no differently from other civilians caught in the 
conflict has come to recognize that displacement puts those affected at a distinct disadvantage. As the director of operations for the ICRC has pointed out: 'Displaced people may have the same need to legal protection as other civilians during conflict, but it goes without saying that, deprived of shelter and their habitual sources of food, water, medicine and money, they have different, and often more urgent, material needs. ${ }^{35}$

Forced to leave their homes, a lack of shelter is IDPs' most obvious particular need. It is therefore all the more surprising that, other than protection, providing IDPs with emergency shelter persistently proves to be among the poorest addressed and most neglected aspects of humanitarian response. ${ }^{36}$ Whereas shelter is a basic component of assistance to refugees, in the case of IDPs, there is no UN agency that predictably meets this need in humanitarian crises. The UN-blue emergency plastic sheeting so evident in refugee camps around the world is conspicuously absent from many IDP camps and settlements. Many IDPs, moreover, are not found in camps but seek out shelter where they can, including in railway cars, aluminum containers, abandoned buildings and urban slums. In Georgia, after nearly a decade of displacement, IDPs were still living in over-crowded and increasingly rundown abandoned sanatoriums, hotels and factories and even in hospital wards. ${ }^{37}$ In some cases, it may be that IDPs who are taken in by relatives, friends or local residents generally fare better. Although, even then, over time the strain placed on the host families can lead to tensions and the risk of IDPs' eviction.

One of the most urgent needs of the internally displaced is food. With limited, if any, access to land and also cut off from their normal means of income, IDPs tend to be more dependent on food assistance than others in the local population. In fact, they typically comprise the majority, of beneficiaries of World Food Programme (WFP) assistance. ${ }^{38}$ In a 2001 policy document, WFP recognized that displacement creates particular vulnerabilities that may not be suffered, at least to the same extent, by the non-displaced, and which increase their food insecurity. ${ }^{39}$ Indeed, malnutrition is among the reasons why some of the highest death rates recorded in humanitarian emergencies this past decade have involved IDPs and why their death rates often have been found to be substantially higher than for nondisplaced populations. ${ }^{40}$ Moreover, IDPs' heightened levels of food and livelihood insecurity do not necessarily improve over time. A recent study by the ICRC and WFP in Colombia found 'no indication that households who have been displaced for a long time have the ability to generate the income needed to obtain sufficient food. ${ }^{\text {41 }}$ The UN Food and Agriculture Organization has underscored the importance of monitoring the household food insecurity of IDPs as well as understanding the 'specific constraints' that prevent them from obtaining required food and ensuring that appropriate measures are undertaken to facilitate this access. ${ }^{42}$

Food insecurity also contributes to other serious health risks. It is well documented that the lack of food and of income-generating opportunities to secure food leads to higher rates of prostitution and sexual exploitation among displaced women and girls. In Uganda, this consequence of the lack of adequate food has resulted in the HIV/AIDS infection rate being six times higher in IDP camps than in the rest of the country. ${ }^{43}$ The World Health Organization, which is man- 
dated by its constitution to assist in providing health services and facilities to "special groups", affirms that "[i]nternally displaced persons represent one of these special groups: a group most vulnerable to health hazards. ${ }^{34}$ Further health risks result from the conditions of poor sanitation, lack of clean water and overcrowding that typically characterize IDP camps and settlements. Epidemics like cholera and tuberculosis commonly arise. ${ }^{45}$ Generally, a lack of access to adequate medical services exacerbates the health situation of many IDPs. The trauma of displacement also accounts for a high prevalence of psychosocial problems among IDPs. In Sri Lanka, it is reported that the suicide rate in IDP camps is three times higher than the national average. ${ }^{46}$

Women and children typically make up the majority of internally displaced populations and face a range of particular risks. Heightened levels of sexual and gender-based violence, in particular among single unaccompanied women and girls as well as women heads of household, have been well documented, though remain poorly addressed. When food is not delivered to women and when, as often is the case, they are excluded from camp management, their vulnerability to sexual abuse and exploitation increases dramatically. Higher rates of domestic violence also are not uncommon. ${ }^{47}$ Trafficking is another serious risk that increases when people are displaced, families are separated and livelihoods are destroyed. Children who have lost their homes and even families are particularly at risk of military recruitment and abuse. Their opportunities to escape these risks are diminished, in both the short and long-term, by the disruption to formal education that displacement typically entails. ${ }^{48}$

Lack of documentation is a common characteristic among the internally displaced as documentation frequently is lost or confiscated during flight. Documentation also may have been destroyed in the course of violent attack or as a result of natural disaster; in Sri Lanka, it is estimated that more than 70 percent of survivors of the tsunami of December 2004 lost their documentation. ${ }^{49}$ Displaced women and children who suddenly find themselves widowed or orphaned may not have documentation in their own names. A lack of documentation can lead to denial of access to health care, education and other government services as well as problems in resolving issues of property restitution or compensation. Moreover, because voting rights almost invariably are tied by laws of general application to the elector's place of residence, a lack of documentation commonly results in the disenfranchisement of the internally displaced, depriving them of a say in the political, economic and social decisions that affect their lives. ${ }^{50}$

The vulnerabilities engendered by displacement do not necessarily diminish over time. As noted above, the ICRC and WFP have found that increased levels of food and livelihood insecurity experienced by the internally displaced can persist long after the emergency phase. The World Bank, in an extensive study of protracted displacement situations in South-eastern Europe and Central Asia, found that after upwards of more than a decade of being forced from their homes, the displaced 'constitute a significant source of vulnerability in affected societies' and that 'the numbers of those who fall into this category are high enough to justify a significant concern.' In particular, the study pointed out that whatever particular 
assistance IDPs had received and continued to rely upon, including government subsidies (it is important to note that theses subsidies often go unpaid ${ }^{51}$ ), free housing in 'rapidly deteriorating makeshift shelters' or long-term dependence on accommodation with relatives and friends, was characterized by 'a fragility...that represents the most disturbing and frequently overlooked aspect of DP [displaced persons'] vulnerability.' The study concluded: 'when multifaceted dimensions of vulnerability are reviewed in conjunction, it is hard to escape the conclusion that the region's DPs are a group deserving continued significant attention from government and donors. ${ }^{52}$

Another distinguishing characteristic of displaced persons is their need for a durable solution to their plight. For IDPs, forced return may be a greater risk than for refugees, who can rely on UNHCR's assistance in monitoring whether conditions of safe and voluntary return or resettlement exist, whereas effective monitoring mechanisms for IDPs' protection do not yet exist. When safe and voluntary return or resettlement does become possible, IDPs, like refugees, require special assistance to rebuild their lives. Yet, despite facing similar problems, and often being in the same circumstances, IDPs rarely receive the same type of reintegration packages provided to refugees. To be sure, host communities, particularly in war-affected countries, likely will require reconstruction assistance as well. However, IDPs inevitably will face particular needs, most notably as regards property and land restitution. Special protection problems may arise as well. Landmines, for instance, usually remain a significant threat long after conflict has ended. Yet, compared to people who have remained in their home areas, displaced persons are at a distinct disadvantage in knowing where mines have been laid in their absence. ICRC statistics and other studies confirm that returning displaced persons and refugees comprise a disproportionate number of civilians injured or killed by landmines. ${ }^{53}$

In summary, it is difficult to deny that IDPs have certain needs that are distinct from the general population and which require special attention. What distinguishes the internally displaced are the unique needs and heightened vulnerabilities that arise as a result of forced displacement, including their need for a durable solution. To be sure, IDPs often are a part of a much larger group of persons in need, whether it be civilians caught up in armed conflict or populations affected by a natural disaster. Nevertheless, the objective fact of being displaced implies particular needs and exposes those affected to additional risks. Quite simply, as human rights expert Roberta Cohen has noted: 'The fact of the matter is that internally displaced persons do have needs that make them different from others in the general population. ${ }^{54}$ Seasoned humanitarian practitioner Dennis McNamara, reflecting on his experience of over thirty years working with populations in situations of war and violence, asserts that there is 'no doubt that the internally displaced have been among the most vulnerable. Not only that, but they also get the least help. ${ }^{35}$ Countless studies corroborate that IDPs have specific needs. There also exists a rich body of evidence demonstrating that humanitarian programming that is not tailored to address the particular situation of the internally displaced often results in assistance that, in the words of one recent evaluation, is 'not in line with...the needs, priorities, and rights of IDPs. ${ }^{56}$ 
It is important to be clear that the purpose of identifying IDPs as a distinct category of concern is not to privilege them over others but rather to ensure that their needs are addressed and their human rights are respected along with those of other persons. To suggest that devoting increased attention to protecting the rights of IDPs runs 'an obvious risk that protection will be limited to that specific category of person, to the detriment of the rest of the population' and risks 'diminishing the protection to which the civilian population as a whole is entitled'57 is misleading. In situations of armed conflict, for instance, ensuring the protection of IDPs does not disqualify other civilians from the guarantees of protection to which they are entitled under international humanitarian law. Generally, focusing on the particular problems of specific groups at risk often will be the best way to ensure that the group is afforded the same protection as others. Tellingly, the Guiding Principles on Internal Displacement begin, in Principle 1, by affirming that IDPs 'shall enjoy, in full equality, the same rights and freedoms [...] enjoyed by other persons in their country. They shall not be discriminated against in the enjoyment of any rights and freedoms on the ground that they are internally displaced.' The principle of equality, however, does not preclude undertaking special measures in the case of a particular group and in fact often will require this. Leading human rights scholars explain: 'Equality in law precludes discrimination of any kind; whereas equality in fact may involve the necessity of different treatment in order to attain a result which establishes an equilibrium between different situations. ${ }^{58}$ International law therefore prescribes, as Walter Kälin points out, that ' $[s]$ ometimes treating internally displaced persons differently in order to respond to their specific needs is unavoidable or even justified. ${ }^{59}$ Programs that do not heed the distinct protection and assistance needs of the internally displaced will otherwise prove inequitable when it comes to the internally displaced. ${ }^{60} \mathrm{~A}$ recent expert report to the United Kingdom's Department for International Development (DFID) echoes this conclusion:

"Attention to equity issues inevitably implies that priority be given to identifying and supporting the most marginalized sections of the population in humanitarian crises. [...] in the pursuit of equity and non-discrimination, DFID and other donor organizations could, in collaboration with other key players such as the UN Representative on IDPs, play a key role in spearheading further discussion and debate on how better to provide for those populations of forced migrants that tend to be left out of conventional provisions. Special emphasis needs to be given to IDPs, who form such a large component of the total displaced population and receive so little support and assistance globally". ${ }^{61}$

This is not to suggest that the needs of IDPs should be blindly prioritized over the concerns of all others. The principle of impartiality, requiring that aid be distributed on the basis solely of need, remains relevant as the core criterion for humanitarian programming. But it also is the case that the internally displaced are likely to be amongst the most vulnerable in any given humanitarian crisis. According to the ICRC: 
"In keeping with its principle of impartiality, the ICRC strives to provide protection and assistance for all conflict victims without distinction and in proportion to their needs, although it is true in many cases that, by virtue of their precarious situation, persons displaced as a result of armed conflict qualify for priority treatment." 22

Awareness from the outset of the heightened vulnerabilities likely to be encountered by IDPs therefore can translate into more effective and efficient humanitarian action. In this regard, the conclusions of a recent study of the humanitarian aid policy of the European Community Humanitarian Office (ECHO), which has long held 'fundamental objections to the identification and treatment of IDPs as a separate group, ${ }^{63}$ are noteworthy:

"The present ECHO policy of targeting on [the] basis of need will generally lead to assistance being targeted to preconceived categories where these are the groups in greatest need and targeting allows for efficient distribution. [...] It is appropriate to target assistance to a specific category, on the basis of assessments or prima facie evidence, that the category of person is more in need than persons outside that category [...] The special needs of some preconceived categories for protection may make it appropriate for $\mathrm{ECHO}$ to continue to fund organizations providing protection to one preconceived category or another" ${ }^{64}$

Of course, it often will make sense to address the plight of IDPs through a broader community-based approach. After all, in some cases, there may not be sharp distinctions between the humanitarian needs of IDPs and those of other populations who have not fled but also are in need. As rightly has been pointed out, "[u]nless segmentation of assistance by target group is part of an overall approach, it is often the source of tensions between host populations and stigmatised displaced populations. ${ }^{35}$ However, there need be no conflict between helping IDPs and helping others. Addressing the specific problems encountered by IDPs does not preclude protecting and assisting other at risk groups; it simply means that the particular needs and vulnerabilities of IDPs are taken into account and addressed, whether through general or targeted programming. In humanitarian assistance programs, identifying priority interventions and striking a balance between general programming and targeted assistance for IDPs should be the goal. As the ICRC's Deputy Director of Operations has pointed out, finding this balance is not only possible but is the principle guiding ICRC assistance programs in situations of internal displacement. ${ }^{66}$

Funding for humanitarian assistance programming must also be flexible so that it can address the needs both of IDPs and of the local non-displaced population who may also be in need. The importance of flexible funding is illustrated by the case of North Sulawesi, Indonesia. A recent study found that after the hostilities and the height of the humanitarian emergency had subsided, the continued automatic prioritization of assistance for IDPs without regard to the humanitarian needs of the local communities led to uneven aid distribution and consequently resulted in deep resentment and hostility towards IDPs that in the end endangered their security. ${ }^{67}$ What the author concluded, however, was not that 
the IDP concept should be jettisoned; on the contrary, 'application of the IDP label calls attention to the special needs and vulnerabilities of the recently displaced' ${ }^{68}$ Rather, what is important is that development programs not be limited to IDPs but also include impoverished members of the local community. ${ }^{69}$

At the same time, it is critical to avoid conceptualizing IDPs and their needs strictly in terms of assistance. To be an IDP does not necessarily mean that one is destitute and in need of aid. As DFID points out, '[n]ot all displaced people are poor - although the great majority are - but their dislocation from physical, social, economic, financial and political capital makes them vulnerable. ${ }^{70}$ To be sure, in any situation there may be exceptional cases of IDPs who have sufficient resources at their disposal and do not need the same humanitarian assistance as the general IDP population or non-displaced groups. Yet, even in those cases, IDPs often encounter particular problems relating to the protection of their human rights, which require special attention. In Georgia, for instance, all IDPs, regardless of socio-economic status, faced restrictions enshrined in national legislation on their right to vote. ${ }^{71}$ In Nepal, the Representative of the Secretary-General found that IDP children across the board faced obstacles as regards the right to education; they were unable to register at school in the areas to which they were displaced without transfer papers from their old school, which due to the security situation they could not return to obtain. ${ }^{72}$ In general, protection always has been the most persistent and critical gap in responses to internal displacement. ${ }^{73}$ The protection problems that IDPs frequently encounter can exist throughout the different phases of displacement and at various levels of humanitarian need. Too often, controversies around the concept of IDPs as a distinct category have framed this debate strictly in terms of material assistance. A recent study of lessons learned from specific emergency situations accordingly recommends the need:

"To ensure clarity in understanding ... of the specific group-based protection needs of IDPs, as a separate issue from the material needs of IDPs (which may or may not vary significantly from those of non-displaced populations); and to work to ensure that the specific protection needs of internally displaced populations are effectively assessed, monitored and responded to wherever possible." 74

From the outset, the IDP concept at its core has been a human rights issue. It was within the human rights framework of the UN, after all, that the plight of the internally displaced emerged on the international agenda and international consensus around the issue was forged. ${ }^{75}$ With a view to further sharpening the focus on IDPs' protection needs, the Commission on Human Rights recently strengthened the human rights aspects of the mandate of the Representative of the Secretary-General on IDPs by explicitly adding reference to "human rights" to the mandate-holder's title. ${ }^{76}$

\section{WHEN DOES INTERNAL DISPLACEMENT END?}

Given that vulnerability leads to IDPs generally being considered a legitimate category of concern, the question arises as to when, in any given situation, should 
the focus on IDPs end and give way to a broader, more situational rather than category-specific approach? Currently, no consensus exists on when to stop counting someone as internally displaced. ${ }^{77}$ For some, internal displacement ends only upon IDPs' return and the effective reversal of their displacement. However, because safe return is not always possible, this can lead to situations where internal displacement holds little prospect of ever ending, and instead is a plight passed down for generations. At the other extreme, internal displacement may end abruptly, even just months after the actual displacement occurred. In some cases, it is the capacity or willingness of the government to provide humanitarian assistance that is the deciding factor. In Croatia, a person can cease to be considered an IDP as a punitive measure, and for the most minor of "offences" such as failure to perform household chores in the collective centre where he or she is living. ${ }^{78}$ Governments may declare internal displacement to have ended in order to give the appearance of the country's return to normalcy, even if actual conditions suggest otherwise. Even among humanitarian organizations engaged with IDPs, the conclusions reached on this issue differ, and often dramatically. For example, the Global IDP Project reports that estimates of the number of internally displaced in Guatemala range from zero to a quarter of a million. ${ }^{79}$ In 2000 in Rwanda, serious differences of opinion arose within the international humanitarian community, including within individual $\mathrm{UN}$ agencies and offices, and the conclusion many reached that displacement had ended continues to be called into question to this day. ${ }^{80}$ In many cases, the decisions taken on this issue violate the rights of the internally displaced.

The Guiding Principles stipulate that "internal displacement shall last no longer than required by the circumstances". However, unlike in refugee law, the Principles do not contain a cessation clause specifying when internal displacement ends. This stems from the fact, as noted above, that the IDP definition, unlike the refugee definition, does not connote a legal status but simply denotes the factual situation of being displaced within one's country. For IDPs who remain in their country, the Principles nonetheless envisage two possible solutions to their displacement: (i) return to their areas of origin or (ii) resettlement in another part of the country. Indeed, the Principles specify a responsibility on the part of the authorities to facilitate these solutions and also stipulate a number of conditions to be met. These include that return or resettlement must occur voluntarily and in conditions of "safety and dignity". IDPs are to be protected against discrimination and to be able to participate fully and equally in public affairs as well as to enjoy equal access to public services. They also are to be assisted to recover or to receive compensation for property and possessions destroyed or of which they were dispossessed as a result of their displacement. These additional provisions suggest that from the standpoint of international law, solutions of IDPs entail much more than simply the physical movement of returning or resettling, but also require putting in place conditions to ensure the durability of these solutions.

Benchmarks as to what a durable solution to internal displacement should entail currently are being developed for the UN, with a view to ensuring less arbitrary approaches to the issue of when internal displacement ends.$^{81}$ Following a series of consultations with a range of representatives from human rights 
organizations, humanitarian agencies, donors, research institutions, civil society groups and, most importantly, the internally displaced themselves, the consensus that is emerging points to the importance of a needs-based approach focusing on the continued existence of IDP-specific needs. Here again, then, vulnerability is the key. With the validity of the IDP concept centered on recognition that the experience of internal displacement exposes its victims to additional vulnerabilities, it follows that a shift in focus away from the internally displaced as a specific category first requires a determination that the distinct risks and vulnerabilities resulting from displacement no longer exist. A series of recent donor evaluations in several different IDP situations echoes this position. Moreover, these donor evaluations underscore that in assessing IDPs' comparative vulnerability, it is important to measure this against the population of the country generally rather than against the situation of groups in close proximity as, particularly in conflict and post-conflict situations as well as in areas devastated by a natural disaster, they too likely will be experiencing heightened levels of vulnerability. ${ }^{82}$ In the solutions phase as well, therefore, a focus on IDPs' specific needs is appropriate, all the while viewed through the lens of a broader community-wide approach.

\section{CONCLUSION}

Internal displacement, though by no means a new phenomenon, has come to the fore in recent years, capturing significant and sustained international attention and concern. Beyond the broad contours of the problem, however, there has not always been a clear understanding of the concept of internal displacement. Indeed, a number of issues have been the subject of intense and often heated debate. Among the key questions have been: Who should be considered to be an "internally displaced person"? Is it right to single out these people as a distinct category of concern? If so, for long should they be considered as IDPs?

There is much to suggest, however, that consensus generally has now crystallized around answers to these conceptual issues. A definition of "internally displaced persons" has been developed and gained wide international standing and recognition. A rich body of empirical evidence delivers a persuasive riposte to questions raised whether IDPs constitute a group with distinct needs warranting specific attention; indeed, it has converted some of the staunchest skeptics. The importance of ensuring that IDPs find a durable solution to their plight that is in line with human rights standards and enables their social, economic and political reintegration, with benchmarks on the issue of when internal displacement ends currently under development.

Key to answering each of these issues has been the concept of vulnerability as well as the principle of equality. In short, ensuring that IDPs can enjoy their human rights in full equality with others requires paying attention to and addressing the specific needs and risks to which the experience of internal displacement exposes them. Effectively responding to the particular plight of IDPs in actual situations remains an operational challenge for many governments as well as for the international community. However, awareness from the outset of the vulner- 
abilities that internal displacement typically entails for the millions of people it affects, whatever the cause of their displacement, is a most essential first step.

\section{Notes}

1 The United Nations Secretary-General, at the request of the Commission on Human Rights (Resolution 1992/73), appointed Francis Deng as his Representative on Internally Displaced Persons in 1992. His successor, Walter Kälin, was appointed in September 2004 as Representative of the Secretary-General on the Human Rights of Internally Displaced Persons.

2 See United Nations Commission on Human Rights, Report of the Representative of the Secretary-General on Internally Displaced Persons, UN doc. E/CN.4/1993/35 (21 January 1993), paras. 33-53; United Nations Commission on Human Rights, Report of the Representative of the Secretary-General on Internally Displaced Persons, UN doc. E/CN.4/1995/50 (2 February 1995), paras. 116-127.

3 Convention Relating to the Status of Refugees (28 July 1951), Article 1.

4 United Nations Commission on Human Rights, Analytical Report of the Secretary-General on Internally Displaced Persons, UN Doc. E/CN.4/1992/23 (14 February 1992), para. 17.

5 Under the Organization of African Unity Convention Governing the Specific Aspects of Refugee Problems in Africa (1969), the term "refugee" encompasses the definition in the 1951 Refugee Convention and "every person who, owing to external aggression, occupation, foreign domination or events seriously disturbing public order in either part or the whole of his country of origin or nationality, is compelled to leave his place of habitual residence in order to seek refuge in another place outside his country of origin or nationality." In Latin America, the Cartagena Declaration on Refugees (1984) defines refugees as persons forced to move "because their lives, safety or freedom have been threatened by generalized violence, foreign aggression, internal conflicts, massive violations of human rights or circumstances which have seriously disturbed public order."

6 United Nations Commission on Human Rights, Report of the Representative of the Secretary-General on Internally Displaced Persons: Guiding Principles on Internal Displacement, UN doc. E/CN.4/1998/53/Add.2 (11 February 1998).

7 UNHCR, Oslo Declaration and Plan of Action, Recommendation 40, Partnership in Action (PARINAC) (June 1994), cited in Roberta Cohen and Francis M. Deng, Masses in Flight: The Global Crisis of Internal Displacement (Washington, D.C.: Brookings Institution, 1998), p. 18.

8 Roberta Cohen, 'The Guiding Principles on Internal Displacement: An Innovation in International Standard Setting,' Global Governance, Vol. 10 (2004), p. 466. See also Cohen and Deng, Masses in Flight, pp. 16-17.

9 See Norwegian Refugee Council Global IDP Project, 'IDP Estimates' at http://www.idpproject.org/statistics.htm; U.S. Committee for Refugees and Immigrants, 'Internally Displaced Persons (as of December 31, 2004),' World Refugee Survey 2005 (Washington, D.C.: USCRI, 2005), p. 12.

10 Stephen Castles and Nicholas Van Hear with Jo Boyden, Jason Hart, Christen Wolff and Paul Ryder, Developing DFID's Policy Approach to Refugees and Internally Displaced Persons, Volume 1: Consultancy Report and Policy Recommendations (Oxford: Refugees Studies Centre, University of Oxford, February 2005), p. 12.

11 Protection of Internally Displaced Persons in Situations of Natural Disasters: A Working Visit to Asia by the Representative of the United Nations Secretary-General on the Human Rights of Internally Displaced Persons Walter Kälin, 27 February to 5 March 2005 (Geneva: Office of the United Nations High Commissioner for Human Rights, 2005), p. 9.

12 See, for instance, "Khartoum Declaration" adopted by the Ministerial Conference on Internally Displaced Persons in the IGAD Sub-Region, Appendix E in Conference on Internal Displacement in the IGAD SubRegion: Report of the Experts Meeting, Khartoum, Sudan, 30 August-2 September 2003 (Washington, D.C.: Brookings Institution-SAIS Project on Internal Displacement, 2003), p. 5.

13 Supplementary Guidance to Humanitarian/Resident Coordinators on their Responsibilities in Relation to Internally Displaced Persons, para. 1. Reproduced in Annex B in Inter-Agency Standing Committee (IASC), Protection of Internally Displaced Persons, IASC Policy Paper Series, no. 2 (New York: United Nations Office for the Coordination of Humanitarian Affairs (OCHA), 2000), p. 27.

14 John Borton, Margie Buchanan-Smith and Ralf Otto, Learning from Evaluations of Support to Internally Displaced Persons. IDP Synthesis Report: Final Report, (Ohain, Belgium: Channel Research, 2005), p. 31.

15 See Walter Kälin, Guiding Principles on Internal Displacement: Annotations. Studies in Transnational Legal Policy, No. 32 (Washington, D.C.: American Society of International Law and the Brookings Institution Project on Internal Displacement), pp. 13-19 [hereinafter Annotations].

16 'Report of the Regional Conference on Internal Displacement in Asia (Bangkok, Thailand, 22-24 February 2000), paras. 12-16, in Refugee Survey Quarterly, Vol. 19, No. 2 (2000), pp. 22-39.

17 Paula Banerjee, Sabyasachi Basu Ray Chaudury and Samir Kumar Das, Internal Displacement in South Asia (New Delhi: Sage, 2005).

18 Discussions at the Workshop on International Migration in West Africa, Dakar, Senegal, 29 September - 5 October 2002 convened by the International Organization for Migration. 
19 Norwegian Refugee Council, Global IDP Project, Internal Displacement: Global Overview of Trends and Developments in 2004 (Geneva: Global IDP Project, Norwegian Refugee Council, 2005), pp. 35-37.

20 Cohen and Deng, p. 17.

21 Regional Seminar on Internal Displacement in the Americas, Mexico City, Mexico, February 18-20, 2004 (Washington, D.C.: Brookings Institution-SAIS Project on Internal Displacement, 2004), p. 12

22 Kälin, Annotations, p. 2.

23 Cohen and Deng, Masses in Flight, p. 18.

24 See Françoise Krill, 'The ICRC's Policy on Refugee and Internally Displaced Civilians,' International Review of the Red Cross, Vol. 83, No. 843 (September 2001).

25 Marguerite Contat Hickel, 'Protection of Internally Displaced Persons affected by Armed Conflict: Concept and Challenges," International Review of the Red Cross, Vol. 83, No. 843 (September 2001), p. 701.

26 'Internally Displaced Persons: The Mandate and Role of the International Committee of the Red Cross,' International Review of the Red Cross, No. 838 (2000), p. 492. See also Questions and Answers: Internally Displaced Persons (ICRC: 2002), p. 3.

27 The International Red Cross and Red Crescent Movement, which is comprised of the ICRC, the International Federation of the Red Cross and National Societies recognizes that internal displacement results from a number of causes, including "armed conflict, violations of international humanitarian law and human rights, and natural and technological disasters". International Red Cross and Red Crescent Movement Action in Favour of Refugees and Internally Displaced Persons, Report Summary and Resolution 4, Council of Delegates, November 2001 (ICRC: 2002), p. 3.

28 Internally Displaced Persons: Questions \& Answers (UNHCR: 2004), pp. 5-6.

29 Françoise Bouchet-Saulnier, 'Using the Law of War to Protect the Displaced', MSF Activity Report 2000-2001 (Paris: Médecins sans Frontières, 2001). That this view is not official policy within MSF, however, is evident from other literature and statements issues by the organization. See, for example, Nicholas de Torrente, 'IDPs in the Caucasus Region and Southeastern Anatolia,' Testimony given for the hearing before the Commission on Security and Cooperation in Europe, $108^{\text {th }}$ U.S. Congress, $1^{\text {st }}$ session, June 10, 2003, CSCE 108-1-2.

30 See, for instance, the remarks of James Hathaway in Proceedings of the $90^{\text {th }}$ Annual Meeting of the American Society of Public International Law (Washington, D.C.: American Society of International Law, 1996), p. 562. See also Contat-Hickel, pp. 708-709.

31 Borton et al., pp. 68-69.

32 Guiding Principle 6. For the legal standards from which this principle is derived, see Kälin, Annotations, pp. 3-19.

33 Borton et al., p. 32

34 Castles et al, p. 29.

35 Jean-Daniel Tauxe, 'We Should Have Humanitarian Access to Displaced Civilians', International Herald Tribune (1 March 2000), p. 10.

36 United Nations Office for the Coordination of Humanitarian Affairs (OCHA), Internal Displacement Division, 'Strengthening UN Agency Accountability in Crises of Internal Displacement', Background paper prepared for the Inter-Agency Standing Committee Working Group, 9 June 2005, p. 1; Norwegian Refugee Council Global IDP Project, Internal Displacement: Global Overview of Trends and Development in 2004 (Geneva: Norwegian Refugee Council, March 2005), p. 30.

37 United Nations Commission on Human Rights, Profiles in Displacement: Georgia. Report of the Representative of the Secretary-General on Internally Displaced Persons, UN doc. E/CN.4/2001/4/Add.4, para. 25. The author accompanied the Representative on this mission.

38 World Food Programme, 'The Right to Food in Emergencies', in The Right to Food in Theory and Practice (Rome: UN Food and Agriculture Organization, 1998).

39 World Food Program, Reaching People in Situations of Displacement: A Framework for Action, WFP/ EB.A/2001/4-C (Rome: World Food Program, 2001).

40 Peter Salama, Paul Spiegel and Richard Brennan, 'No Less Vulnerable: The Internally Displaced in Humanitarian Emergencies,' The Lancet, Vol. 357, No. 9266 (5 May 2001).

${ }^{41}$ IDPs in Colombia: A Joint Needs Assessment by the ICRC and the World Food Programme (Geneva: ICRC, 22 April 2005).

42 IASC, Protection of Internally Displaced Persons, p. 22.

43 'HIV Prevalence among IDPs Stands at 35 Percent', The Monitor (30 June 2005).

44 IASC, Protection of Internally Displaced Persons, p. 22

45 See, for example, Centers for Disease Control, 'Cholera Epidemic After Increased Conflict: Monrovia, Liberia, June-September 2003', Morbidity and Mortality Weekly Report, Vol. 52, No. 45 (2003); D.M. Weinstock, O. Hahn, M. Wittkamp, K.A. Sepkowitzm, G. Khechinashvili G and H. M. Blumberg, 'Risk for Tuberculosis Infection Among Internally Displaced Persons in the Republic of Georgia', International Journal of Tuberculosis and Lung Disease, Vol. 5, No. 2 (2001), pp. 164-169.

46 Save the Children, State of the World's Mothers 2003: Protecting Women and Children in Conflict (Westport, Connecticut: Save the Children USA, 2003), p. 11. 
47 See, for example, 'International Women's Day: Colombia's Displaced Women Tell of their Suffering,' (Bogota, Colombia: UNHCR, 8 March 2005).

48 Erin Mooney and Colleen French, Barriers and Bridges: Access to Education for Internally Displaced Children (Washington, D.C.: Brookings Institution, 2005).

49 Protection of Internally Displaced Persons in Situations of Natural Disaster, pp. 19-20.

50 Erin Mooney and Balkees Jarrah, 'Safeguarding IDP Voting Rights', Forced Migration Review, Issue 23 (May 2005), p. 55; Erin Mooney and Balkees Jarrah, The Voting Rights of Internally Displaced Persons: The OSCE Region (Washington, D.C.: Brookings Institution, November 2004).

51 See United Nations Commission on Human Rights, Profiles in Displacement: Georgia.

52 Steven B. Holtzman and Taies Nezam, Living in Limbo: Conflict-Induced Displacement in Europe and Central Asia (Washington, D.C.: The World Bank, 2004), pp. 135-136.

53 Mine/UXO Awareness Programmes for Internally Displaced Persons and Returnees (ICRC: 2002). See also J. Clover, 'Angola's Children: Bearing the Greatest Cost of the War', African Security Review, Vol. 11, No. 3 (2002), pp. $103,105$.

54 Roberta Cohen, Statement before the World Food Programme Consultation on Humanitarian Issues, Rome, Italy, 16 March 2000, p. 3.

55 Dennis McNamara, 'Refugees in Their Own Lands: Internally Displaced are Among the World's Most Vulnerable. The G8 Must Not Ignore Them Again', The Guardian (28 June 2005), p. 24.

56 See Borton et al, p. 40.

57 Contat-Hickel, p. 708; Questions and Answers: Internally Displaced Persons (ICRC: 2002), p. 3.

58 Henry J. Steiner and Philip Alston, International Human Rights in Context: Law, Politics, Morals (Oxford: Oxford University Press, 1996), p. 93.

59 Kalin, Annotations, p. 7. See also ibid., p. 12.

60 Cohen, Statement before the World Food Programme, p. 3.

61 Castles et al., p. 56.

62 Questions and Answers: Internally Displaced Persons (ICRC: 2002), p. 3.

63 Borton et al., pp. 98-99.

64 John Cosgrave, Synthesis of Findings on ECHO's Policy of Treating Affected Populations Without Regard to Preconceived Categories, Specifically IDPs, Refugees and Returnees, and Local Population, based on Reviews in Sudan, Angola and Afghanistan (Brussels: ECHO, 2004), p. 6, cited in Buchanan et al., p. 71.

65 Contat Hickel, p. 708.

66 Krill, p. 621. See also p. 610.

67 Christopher Duncan, 'Unwelcome Guests: Relations between Internally Displaced Persons and Their Hosts in North Sulawesi, Indonesia', Journal of Refugee Studies, Vol. 18, No. 1 (2005).

68 Ibid., p. 28.

69 Ibid., p. 42.

70 Government of the United Kingdom, Department for International Development, 'Terms of Reference: Developing DFID's Policy Approach to Refugees, Asylum Seekers and Internally Displaced People,' Annex I in Castles et al., p. 153.

71 Mooney and Jarrah, pp. 32-41.

72 United Nations Commission on Human Rights, Report of the Representative of the Secretary-General on the Human Rights of Internally Displaced Persons: Mission to Nepal, April 2005 (forthcoming).

73 That this remains the case is evident from a recent multi-country evaluation of international responses to internal displacement. Simon Bagshaw and Diane Paul, Protect or Neglect: Toward a More Effective United Nations Approach to the Protection of Internally Displaced Persons (Washington, D.C.: Brookings-SAIS Project on Internal Displacement and the UN Office for the Coordination of Humanitarian Affairs Inter-Agency Internal Displacement Division, 2004).

74 Sarah Collinson, 'Lessons Learned from Specific Emergency Situations: A Synthesis', in Castles et al., Developing DFID's Policy Approach to Refugees and Internally Displaced Persons, Volume II: Commissioned Papers, p. 26.

75 United Nations Commission on Human Rights resolution 1992/73.

76 United Nations Commission on Human Rights resolution 2004/55.

77 See Erin Mooney, 'Bringing the End into Sight for Internally Displaced Persons', Forced Migration Review, Issue 17 (2003), pp. 4-7

78 Christophe Beau, 'National Legislation', Forced Migration Review, Issue 17 (May 2003), p. 18.

79 Norwegian Refugee Council Global IDP Project, Guatemala Country Profile posted at: http://www.db.idpproject. org/Sites/IdpProjectDb/idpSurvey.nsflwCountriesb/Guatemala

80 Norwegian Refugee Council Global IDP Project, Ensuring Durable Solutions for Rwanda's Displaced People: A Chapter Closed Too Early (8 July 2005) at www.idpproject.org

81 Mooney, 'Bringing the End into Sight.'

82 Borton et al., p. 104. 